\title{
Spreading the clinical window for diagnosing fetal-onset hypogonadism in boys
}

\author{
Romina P. Grinspon, Nazareth Loreti, Débora Braslavsky, Clara Valeri, Helena Schteingart, \\ María Gabriela Ballerini, Patricia Bedecarrás, Verónica Ambao, Silvia Gottlieb, María Gabriela Ropelato, \\ Ignacio Bergadá, Stella M. Campo and Rodolfo A. Rey*
}

Centro de Investigaciones Endocrinológicas "Dr. César Bergadá" (CEDIE), CONICET, FEl, División de Endocrinología, Hospital de Niños Ricardo Gutiérrez, Buenos Aires, Argentina

\section{Edited by:}

Rebecca Christine Knickmeyer, The University of North Carolina at Chapel Hill, USA

\section{Reviewed by:}

Alan David Rogol, University of

Virginia, USA

Raja Brauner, Université Paris

Descartes, France

\section{${ }^{*}$ Correspondence}

Rodolfo A. Rey, Centro de

Investigaciones Endocrinológicas "Dr. César Bergadá" (CEDIE), CONICET,

FEl, División de Endocrinología,

Hospital de Niños Ricardo Gutiérrez,

Gallo 1330, Buenos Aires C1425EFD,

Argentina

e-mail: rodolforey@cedie.org.ar
In early fetal development, the testis secretes - independent of pituitary gonadotropins androgens and anti-Müllerian hormone (AMH) that are essential for male sex differentiation. In the second half of fetal life, the hypothalamic-pituitary axis gains control of testicular hormone secretion. Follicle-stimulating hormone (FSH) controls Sertoli cell proliferation, responsible for testis volume increase and $\mathrm{AMH}$ and inhibin $\mathrm{B}$ secretion, whereas luteinizing hormone (LH) regulates Leydig cell androgen and INSL3 secretion, involved in the growth and trophism of male external genitalia and in testis descent. This differential regulation of testicular function between early and late fetal periods underlies the distinct clinical presentations of fetal-onset hypogonadism in the newborn male: primary hypogonadism results in ambiguous or female genitalia when early fetal-onset, whereas it becomes clinically undistinguishable from central hypogonadism when established later in fetal life. The assessment of the hypothalamic-pituitary-gonadal axis in male has classically relied on the measurement of gonadotropin and testosterone levels in serum. These hormone levels normally decline 3-6 months after birth, thus constraining the clinical evaluation window for diagnosing male hypogonadism. The advent of new markers of gonadal function has spread this clinical window beyond the first 6 months of life. In this review, we discuss the advantages and limitations of old and new markers used for the functional assessment of the hypothalamic-pituitary-testicular axis in boys suspected of fetal-onset hypogonadism.

Keywords: hypopituitarism, cryptorchidism, micropenis, disorder of sex development, testosterone
The concept of male hypogonadism is usually associated with the adult patient, and rarely thought of as a condition in the prepubertal boy. Furthermore, male hypogonadism is most frequently equated to hypoandrogenism. Androgens are the dean of testicular hormones, and the normal testis produces very little or no testosterone during most of infancy and childhood. It is therefore easy to understand why the term hypogonadism is almost absent from the pediatrician's terminology. However, many hypogonadal states in the male bear their origin in fetal life. With the advent of direct markers of Sertoli cell function, hypogonadism can be identified in boys beyond the early postnatal critical window of pituitary-gonadal activation (1) - called "mini-puberty" by some authors - and before pubertal age. In this review, we address the diagnostic approaches of fetal-onset male hypogonadism based on the physiology and pathophysiology of the hypothalamic-pituitary-testicular axis ontogeny.

\section{ONTOGENY OF THE \\ HYPOTHALAMIC-PITUITARY-TESTICULAR AXIS}

\section{FETAL LIFE: THE FIRST VERSUS THE SECOND AND THIRD TRIMESTERS}

The gonadotropin-releasing hormone $(\mathrm{GnRH})$ neurons derive from cells present in the nasal placode in the sixth fetal week (2), which migrate together with olfactory axons and blood vessels through the cribriform plate and arrive in the developing forebrain in the 9th-10th weeks. Several genes are involved in the development and migration of $\mathrm{GnRH}$ neurons, including KAL1, FGF8, FGFR1, PROK2, PROKR2, CHD7, WDR11, and NELF, and in their homeostasis and function, including DAX1 (or NR0B1), LEP, LEPR, KISS1, KISS1R, TAC3, TACR3, and GNRH1 [reviewed in Ref. $(3,4)]$.

The pituitary gonadotropes develop in the Rathke's pouch following a sequential differentiating pathway, which also includes the other pituitary cell lineages, from the oral ectoderm ancestor. Early genes, like SHH, GLI1, GLI2, LHX3, LHX4, PITX1, PITX2, $O T X 2$, and HESX1, are involved in the differentiation of all pituitary cell lineages, whereas TBX19 (or TPIT), GATA2, and SF1 (or $N R 5 A 1)$ are more specifically related to the gonadotrope lineage [reviewed in Ref. (5)]. Fully functional gonadotropes are present in the fetal male pituitary and secrete luteinizing hormone (LH) from week 12 and Follicle-stimulating hormone (FSH) from week 14 (6). Circulating levels of both gonadotropins increase to attain peak levels by weeks 20-25 and then decrease toward term (7-9).

The testes differentiate from the adreno-gonadal primordium by the seventh week of gestation. Interestingly, Sertoli cells actively secrete anti-Müllerian hormone (AMH), involved in the regression of the uterine anlage during the eighth and ninth weeks, i.e., before exposure to FSH. In fact, basal AMH expression is triggered by SOX 9 and enhanced by SF1, GATA4, and WT1 independent of 
FSH [reviewed in Ref. (10)]. Afterward, FSH increases testicular AMH output by inducing Sertoli cell proliferation and AMH transcription following the classic FSH receptor transduction pathway involving protein kinase A and cyclic AMP $(10,11)$. Sertoli cells also secrete inhibin $B$, which is present at high levels in the serum of mid-term fetuses and only slightly lower by term $(8,9)$. Sertoli cells are not directly regulated by androgens during fetal life since they do not express the androgen receptor [reviewed in Ref. (12)].

Approximately 1 week later than Sertoli cells do, Leydig cells differentiate in the interstitial tissue and secrete testosterone, responsible for the differentiation of the male gonaduct, the prostate, and the external genitalia, independently from fetal pituitary LH. In fact, the major regulator of testosterone production during the first trimester is chorionic gonadotropin (hCG), which circulates at high levels in fetuses with a peak at $12-17$ weeks subsequently decreasing through term $(7,13)$. The relevance of fetal LH in Leydig cell function becomes more evident during the second and third trimesters. Both LH and hCG act on the same transmembrane receptor, the LHCG-R, present on the Leydig cell membrane and inducing cell proliferation and differentiation as well as androgen and insulin-like 3 (INSL3) synthesis and secretion. Male differentiation of internal and external genitalia is completed in the first trimester (Figure 1). Afterward, androgens induce the growth of the phallus and the trophism of the scrotum, whereas both androgens and INSL3 are important for testicular descent (14).

\section{POST-NATAL LIFE: INFANCY, CHILDHOOD, AND PUBERTY}

The decreasing trend in the whole hypothalamic-pituitarytesticular axis activity is reflected in low perinatal levels of all hormones (Figure 2) (9). Thereafter, an increase in circulating levels is observed in the neonate already by the end of the first week for gonadotropins, and from the second to fourth weeks for $\mathrm{AMH}$, inhibin $\mathrm{B}$, and testosterone $(15,16)$. It should be noted for testosterone that serum samples must be extracted to avoid interferences that artificially overestimate results (Figure 2). LH drives testosterone and INSL3 to peak levels during the third month; thereafter, they all decline and attain very low or undetectable levels after the sixth month (Figure 1) (16-18). Assays for INSL3 are now commercially available, with sufficient sensitivity to be used in patients during childhood (19), although an hCG test may be needed.

On the other hand, FSH continues to induce Sertoli cell proliferation resulting in a continuous increase in testis volume. Androgens may also exert a proliferative effect on Sertoli cells (20), but the effect should be indirect since the androgen receptor is still not expressed in Sertoli cells during early infancy [reviewed in Ref. (12)]. It should be noted that the absolute volume increment described in this period of life is modest $(<1.5 \mathrm{~mL})$ and cannot be clinically evidenced by palpation $(21)$. $\mathrm{AMH}$ and inhibin B secretion is also enhanced: the levels of both hormones increase progressively through infancy (Figure 1)

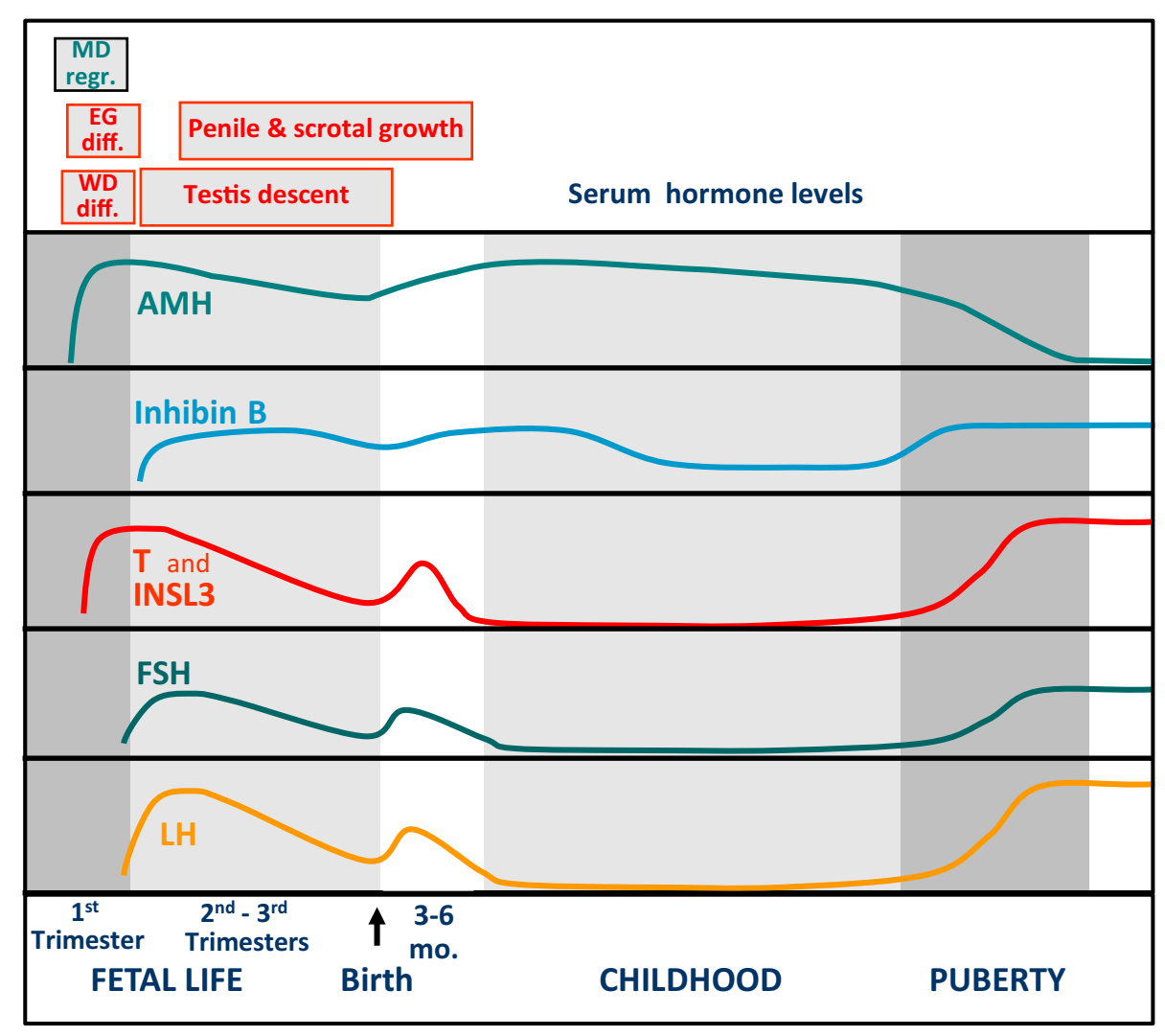

FIGURE 1 | Schematic representation of the pituitary-testicular axis hormone levels and of sexual differentiation and development of male internal and external genitalia. WD diff., Wolffian duct differentiation; MD regr., Müllerian duct regression; EG diff., differentiation of the external genitalia. 

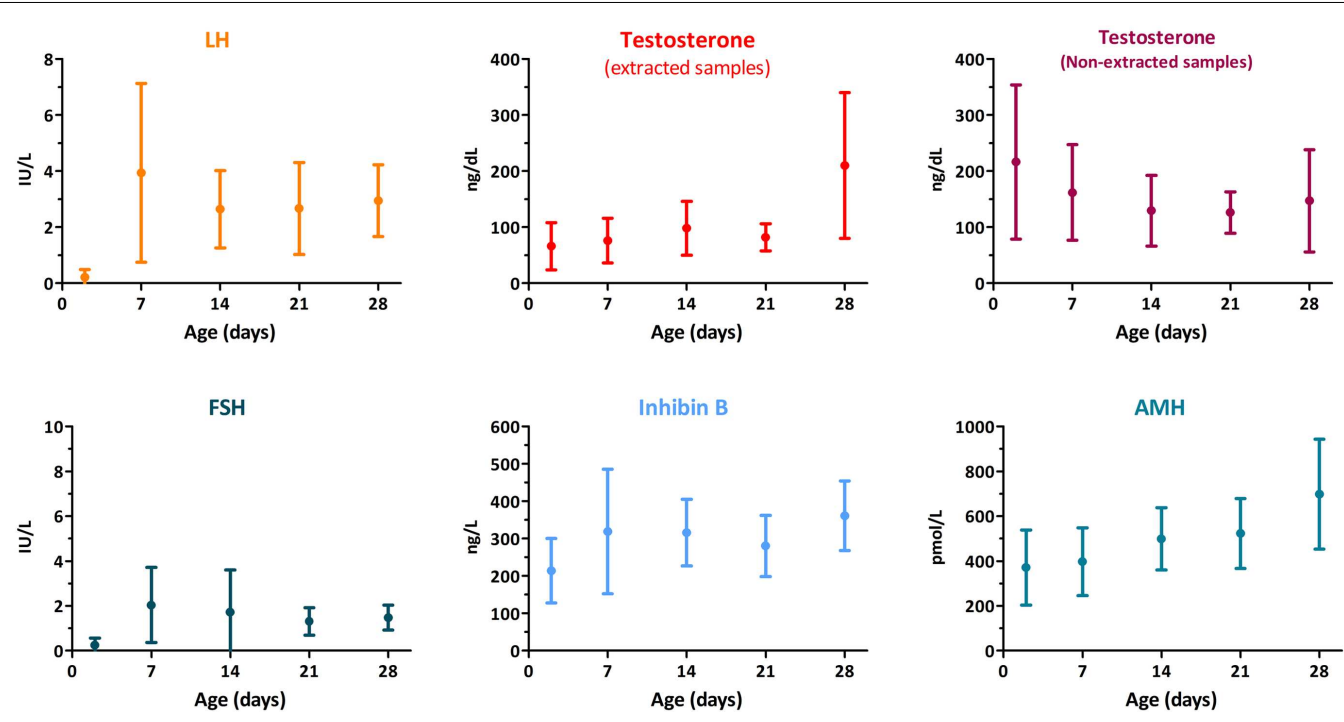

FIGURE 2 | Serum levels of gonadotropins and testicular hormones in male newborns. Data obtained from Ref. (15)

$(15,22,23)$. The increase observed during the first months of life may be linked to the marked proliferation of Sertoli cells that occurs after mid-gestation with a further increment after birth (24), probably enhanced by the post-natal gonadotrophic surge. Serum inhibin B levels are as high as those observed in pubertal boys during the first 6 months of age; thereafter, a progressive fall occurs until the age of 4-6years, but serum concentrations remain considerable, since they are above the lowest limit of normal adult range (23), and can be readily detected with the commercially available new generation assays (25). Serum AMH peaks during the second year and then remains fairly stable during childhood $(22,26)$. Altogether, these data clearly indicate that Sertoli cells are functionally active during infancy and childhood.

Testosterone and inhibin $\mathrm{B}$ are the most relevant physiological factors involved in gonadotropin negative feedback in the adult. A possible role for inhibin B in FSH negative feedback before puberty is still a matter of debate. Higher FSH than LH levels observed in boys with no functional gonadal tissue (27-29), the inverse correlation between FSH and inhibin B levels observed in cryptorchid boys (30), and the suppression of FSH secretion observed in prepubertal patients with Sertoli cell neoplastic proliferations and increased inhibin B (31) support the hypothesis of the active role that inhibin B has in regulating FSH. However, the decrease in $\mathrm{LH}$ and FSH levels during normal male childhood is not fully dependent on these testicular hormones, since it also occurs in a considerable proportion of boys with gonadal dysgenesis (27) or anorchia (Figure 3) (29).

A progressive increase in gonadotropin pulse amplitude and frequency occurring between 9 and 14 years of age triggers testicular pubertal maturation. LH induces Leydig cells androgen production again: intratesticular testosterone concentration increases and acts on Sertoli cells, which now express the androgen receptor. Consequently, they acquire a mature phenotype characterized by the development of the blood-testis barrier and a down-regulation of AMH production [reviewed in Ref. (12)]. The rise in serum testosterone occurs 1-2 years later $(32,33)$. Germ cells, hitherto limited to spermatogonia, enter meiosis and go through the complete spermatogenic process giving rise to spermatozoa. Spermatogenic development is responsible for the remarkable increase of testis volume during puberty. FSH and germ cells induce an increase in inhibin B. Serum levels of inhibin B increase concomitantly with testicular volume, and attains adult levels as early as pubertal stage II $(23,34,35)$. INSL3 secretion also increases during puberty (36); in adult, the production and secretion of INSL3 is maintained by the long-term trophic effect of LH on Leydig cell structure and function and independent of the acute steroidogenic effect of LH (16).

\section{DEFINITION AND CLASSIFICATION OF CONGENITAL MALE HYPOGONADISM}

From the comprehension of the changes occurring in the normal physiology of the pituitary-testicular axis during pre- and postnatal life, it emerges clearly that male hypogonadism cannot be limited to hypoandrogenism. The definition should be extended to all situations characterized by a decreased testicular function, as compared to what is expected for age, involving an impaired hormone secretion by Leydig cells (androgens, INSL3) and/or Sertoli cells (AMH, inhibin B) and/or a disorder of spermatogenesis (Table 1).

It should also be considered that the clinical manifestations of male hypogonadism will vary according to: (a) the level of the hypothalamic-pituitary-testicular axis primarily affected, (b) the testicular cell population initially impaired, and (c) the period of life when the condition is established (37).

\section{LEVEL OF THE AXIS PRIMARILY AFFECTED: CENTRAL, PRIMARY, OR COMBINED HYPOGONADISM}

In central (or hypothalamic-pituitary) hypogonadism, testicular failure is secondary to a disorder affecting the secretion of GnRH 

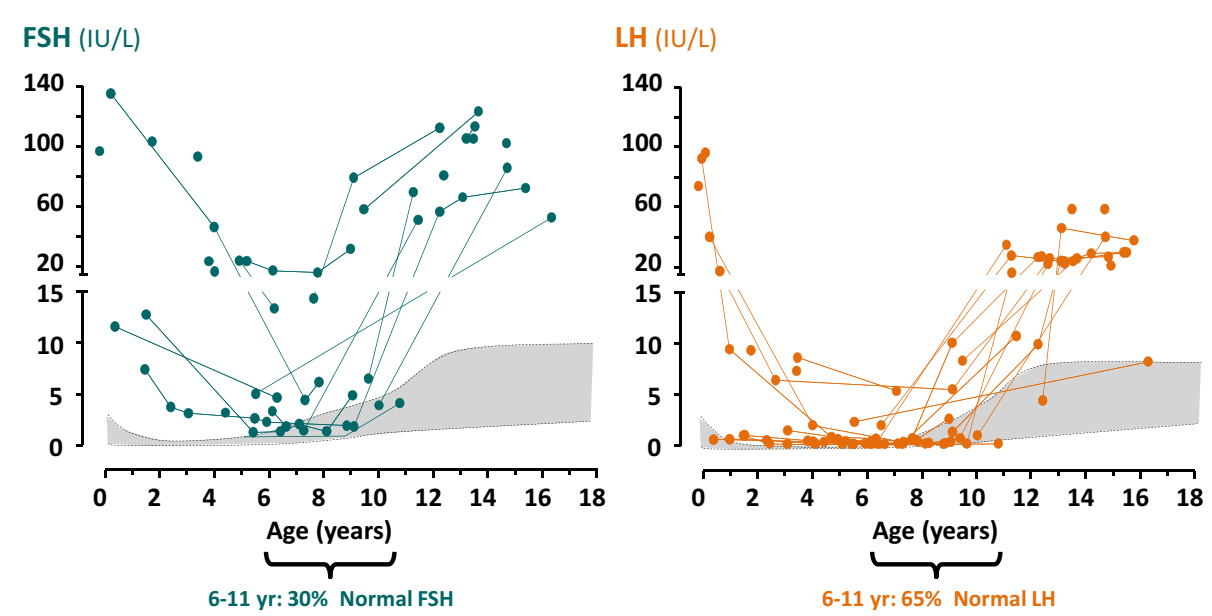

FIGURE 3 | Serum levels of gonadotropins in anorchid boys. Reproduced from Ref. (29), C2012 Blackwell Publishing Ltd., with permission from Blackwell Publishing Ltd., John Wiley and Sons.

Table 1 | Classification of fetal-onset male hypogonadism.

\begin{tabular}{|c|c|c|}
\hline & $\begin{array}{l}\text { Whole gonadal } \\
\text { dysfunction }\end{array}$ & $\begin{array}{l}\text { Cell-specific gonadal } \\
\text { dysfunction }\end{array}$ \\
\hline \multicolumn{3}{|c|}{ PRIMARY HYPOGONADISM } \\
\hline First trimester & Gonadal dysgenesis & $\begin{array}{l}\text { Leydig cells } \\
\text { LHCG-R mutation } \\
\text { Steroidogenic protein } \\
\text { defects } \\
\text { Sertoli cells } \\
\text { AMH mutation }\end{array}$ \\
\hline \multirow[t]{2}{*}{$\begin{array}{l}\text { Second - third } \\
\text { trimesters }\end{array}$} & $\begin{array}{l}\text { Testicular regression } \\
\text { syndrome } \\
\text { Testicular torsion }\end{array}$ & $\begin{array}{l}\text { Leydig cells } \\
\text { INSL3 mutation }\end{array}$ \\
\hline & Endocrine disruptors & $\begin{array}{l}\text { Sertoli cells } \\
\text { FSH-R mutation }\end{array}$ \\
\hline \multicolumn{3}{|c|}{ CENTRAL HYPOGONADISM } \\
\hline $\begin{array}{l}\text { Second - third } \\
\text { trimesters }\end{array}$ & $\begin{array}{l}\text { Multiple pituitary hormone } \\
\text { deficiency } \\
\text { Isolated hypogonadotropic } \\
\text { hypogonadism (IHH) }\end{array}$ & $\begin{array}{l}\text { Leydig cells } \\
\text { LH } \beta \text {-subunit gene } \\
\text { mutation } \\
\text { Neurokinin defects } \\
\text { Sertoli cells } \\
\text { FSH } \beta \text {-subunit gene } \\
\text { mutation }\end{array}$ \\
\hline \multicolumn{3}{|c|}{ COMBINED HYPOGONADISM } \\
\hline First trimester & DAX1 gene mutations & None \\
\hline $\begin{array}{l}\text { Second - third } \\
\text { trimesters }\end{array}$ & Prader-Willi syndrome & None \\
\hline
\end{tabular}

or gonadotropins. It is usually characterized by an impaired production of both LH and FSH, and thus called hypogonadotropic hypogonadism; however, as discussed later, this nomenclature is not always applicable, and some cases of central hypogonadism may present with normal or even increased levels of one gonadotropin.
In primary hypogonadism, the testis is the primarily affected organ. This may lead to an impaired production of testicular hormones and a disruption of the negative feedback to the hypothalamic-gonadotrope axis, which results in an elevation of FSH and/or LH. In adult endocrinology, primary hypogonadism is usually identified as hypergonadotropic; however, as discussed in the previous section, during childhood, primary hypogonadism or even agonadism - may present with normal gonadotropin levels (27-29).

In certain disorders, both the hypothalamic-gonadotrope axis and the testis are affected concomitantly, e.g., in DAX1 mutations or in oncologic patients exposed to cranial radiotherapy and chemotherapy. These "dual" conditions are characterized by a lack of gonadotropin elevation during puberty or adulthood in spite of the low testicular secretion of androgens and/or inhibin B [reviewed in Ref. (37)].

\section{WHOLE TESTICULAR VERSUS SPERMATOGENIC, LEYDIG CELL-SPECIFIC OR SERTOLI CELL-SPECIFIC FAILURE}

Whole testicular failure or hypogonadism reflects the concomitant impairment of all testicular cell populations. On the contrary, the disorder may primarily involve only one testicular cell population; for instance, spermatogenic-specific failure results from Yq chromosome deletions, steroidogenic failure from defects in $\mathrm{LH}$, its receptor or steroidogenic enzymes, and Sertoli cell-specific hypogonadism from defects in FSH or its receptor or in the $\mathrm{AMH}$ gene, as we discuss more in detail below.

\section{ONSET OF MALE HYPOGONADISM: FETAL VERSUS POST-NATAL LIFE}

Male hypogonadism can be congenital, i.e., fetal-onset hypogonadism, or result from a condition acquired during post-natal life. The clinical presentation depends on the period of life in which testicular failure is established. In adulthood, androgen deficiency leads to decreased libido, impotence, fatigue, loss of bone and muscle mass, increased fat mass and metabolic disorders, and spermatogenic failure results in oligo- or azoospermia. At pubertal age, male hypogonadism results in the absence or the arrest 
of pubertal development. Because the hypothalamic-pituitarysteroidogenic function is normally low during childhood - as explained above - male hypogonadism remains clinically unapparent when established in this period of life unless suspected and actively sought for by measuring serum AMH or inhibin B in basal conditions, or testosterone or INSL3 after stimulation with hCG [reviewed in Ref. (37)]. Fetal-onset hypogonadism may lead to a variety of clinical presentations, which are discussed in detail below.

\section{PATHOPHYSIOLOGY OF FETAL-ONSET MALE HYPOGONADISM}

The clinical consequences of fetal-onset male hypogonadism can be deduced from the understanding of the normal ontogeny of the male reproductive axis during fetal life described above. When established in the first trimester, the lack or insufficient levels of testis hormones during the critical window of male sex differentiation (weeks 8-13) lead to disorders of sex development (DSD) presenting with female or ambiguous genitalia. Because Leydig cell androgen production is essentially under placental hCG - not fetal LH - control in the first trimester, central hypogonadism does not result in DSD. Primary hypogonadism established in the second half of gestation and central hypogonadism lead to a decreased number of Sertoli cells and also to an impaired testicular output of androgens and INSL3. The clinical consequences are microorchidism, micropenis, and cryptorchidism.

\section{PRIMARY HYPOGONADISM ESTABLISHED IN THE FIRST TRIMESTER Whole testicular dysfunction: gonadal dysgenesis}

Gonadal dysgenesis may result from chromosomal aberrations or mutations affecting genes controlling testicular differentiation (Table 2). Chromosome aberrations involving the short arm of the $Y$ chromosome cause gonadal dysgenesis affecting all cell populations. Similarly, deletions of the short arm of chromosome 9 - where DMRT1 and DMRT2 map (38) - and duplications of Xp21.3-p21.2 - where DAX1 gene maps (39) and of 1p31-p35 where WNT4 maps (40) - result in testicular dysgenesis. 46,XY patients with mutations in SRY (41) or MAMLD1 (42) also present with gonadal dysgenesis. Mutations in other genes associate testicular dysgenesis with dysfunctions of other organs (Table 2). SF1 mutations may associate gonadal dysgenesis with adrenal failure (43), yet isolated testicular dysfunction can be observed (44). Mutations in WT1 result in gonadal dysgenesis associated with degenerative renal disease, resulting in Denys-Drash syndrome or in Frasier syndrome (45). Haploinsufficiency of SOX9 leads to a polymalformative syndrome including gonadal dysgenesis, bowing and angulation of long bones (known as campomelic dysplasia), hip dislocation, hypoplastic scapula, small thoracic cage, macrocephaly, facial dysmorphism, and cardiac and renal defects $(40,46)$. Homozygous mutations of $\mathrm{DHH}$ gene result in the association of gonadal dysgenesis and minifascicular neuropathy (47, 48). Mutations in $\mathrm{XH} 2$ gene cause the ATRX syndrome, characterized by $\alpha$-thalassemia, mental retardation, facial dysmorphism and gonadal dysgenesis (49). Recently, MAP3K1 mutations have been identified as another cause of partial or complete gonadal dysgenesis (50). Finally, mutations in TSPYL1 have been found in patients with gonadal dysgenesis and sudden death (51). However, the vast majority of dysgenetic DSD cases remain unexplained, which suggests that several other gene defects may be the underlying cause.

Exposure to environmental disruptors in utero has also been implicated as the underlying cause for interlinked reproductive disorders like cryptorchidism, hypospadias, infertility and testicular cancer, which seem to show an increasing trend. This association is known as the testicular dysgenesis syndrome (52).

When the gonadal dysgenesis is complete, internal and external genitalia differentiate along the female pathway since the streak gonads do not secrete any androgens or AMH. These 46,XY girls are apparently normal and do not seek medical attention until pubertal age when they present with absence of telarche and menarche. Only in the case of contradiction between a karyotype performed during gestation and the lack of virilization, does the case present to the specialist immediately after birth.

In partial forms of testicular dysgenesis, the degree of undervirilization depends on the amount of functional gonadal tissue the patient has. The external genitalia may be more or less ambiguous, testes do not descend and Wolffian derivatives are more or less atrophic as signs of insufficient androgen secretion, reflecting Leydig cell dysfunction. The persistence of müllerian derivatives reflects defective AMH production as a sign of Sertoli cell dysfunction.

In both complete and partial forms, the androgen and inhibin $B$ feedback mechanisms are insufficient and the gonadotrope secretion of gonadotropin is exaggerated.

\section{Leydig cell-specific dysfunction: isolated fetal hypoandrogenism}

When only Leydig cell development and/or function are primarily disturbed in the first trimester of fetal life, insufficient androgen production results in undervirilisation and cryptorchidism. On the contrary, Sertoli cells are normally active and secrete $\mathrm{AMH}$ which induces full regression of Müllerian ducts. Therefore, this apparently normal girl has no uterus and a short blind-end vagina. Similar to complete gonadal dysgenesis, these patients seek medical attention at pubertal age because of the absence of telarche and primary amenorrhea. In the cases of a partial defect, androgen secretion is insufficient to virilize the fetus adequately: the newborn has ambiguous external genitalia and hypotrophic Wolffian duct derivatives. The degree of virilization is commensurate with the residual steroidogenic activity of the gonads. The gonadotrope secretes excessive gonadotropins with an increased LH:FSH ratio, because FSH is negatively regulated by inhibin $\mathrm{B}$.

Leydig cell aplasia is a rare form of isolated fetal hypoandrogenism leading to a DSD due to inactivating mutations of the LHCG-R (Table 3) [reviewed in Ref. (53)]. Defective androgen production by the testis can also result from mutations in one of the five enzymatic activities necessary for the synthesis of testosterone from cholesterol (Table 3). Three of these are common to adrenal and gonadal steroidogenesis: cholesterol side-chain cleavage (P450scc), $3 \beta$-hydroxysteroid dehydrogenase ( $3 \beta-\mathrm{HSD})$, and $17 \alpha$-hydroxylase (P450c17). A deficiency in any of these in $46, \mathrm{XY}$ individuals results in testicular hypoandrogenism leading to genital ambiguity and adrenal insufficiency leading to congenital adrenal hyperplasia. Two steroidogenic steps - 17,20-lyase (activity contained in $\mathrm{P} 450 \mathrm{c} 17$ ) and $17 \beta$-hydroxysteroid dehydrogenase 
Table 2 | Clinical features in male patients with fetal-onset primary hypogonadism with whole gonadal dysfunction.

\begin{tabular}{|c|c|c|c|}
\hline Affected chromosome & Gene & OMIM & Associated clinical features \\
\hline 9p24 deletion & $D M R T 1$ and $D M R T 2$ & \#154230 & $\begin{array}{l}\text { Dysgenetic DSD } \\
\text { Mental retardation, microcephaly, facial malformations, short stature } \\
\text { Digestive or bronchial malformations }\end{array}$ \\
\hline Xp21 duplication & $D A X 1=N R O B 1$ and other genes & \#300018 & Dysgenetic DSD \\
\hline Xq28 & MAMLD1 & *300120 & Dysgenetic DSD \\
\hline $9 q 33.3$ & $S F 1=N R 5 A 1$ & +184757 & $\begin{array}{l}\text { Dysgenetic DSD } \\
\text { Adrenal insufficiency }\end{array}$ \\
\hline $12 q 13.12$ & $\mathrm{DHH}$ & \#233420 & $\begin{array}{l}\text { Dysgenetic DSD } \\
\text { Minifascicular neuropathy }\end{array}$ \\
\hline$X q 21.1$ & $A T R X=X H 2$ & \#301040 & $\begin{array}{l}\text { Dysgenetic DSD } \\
\text { Mental retardation, } \alpha \text {-thalassemia }\end{array}$ \\
\hline $5 q 11.2$ & MAP3K1 & \#613762 & Dysgenetic DSD \\
\hline $6 q 22.1$ & TSPYL1 & \#608800 & $\begin{array}{l}\text { Dysgenetic DSD } \\
\text { Sudden infant death }\end{array}$ \\
\hline
\end{tabular}

DSD, disorder of sex development; OMIM, Online Mendelian Inheritance in Man locus, gene and phenotype numbers (http://www.ncbi.nlm.nih.gov/omim).

(17 $\beta$-HSD) - are required only for gonadal steroidogenesis; therefore, their defects result only in hypovirilization without adrenal insufficiency [reviewed in Ref. (53)].

\section{Sertoli cell-specific dysfunction: $A M H$ deficiency}

The persistent Müllerian duct syndrome (PMDS) is a rare form of DSD characterized by persistence of Müllerian derivatives in otherwise normally virilized 46,XY individuals. Regression of Müllerian ducts normally occurs between 8 and 10 weeks of fetal development, under the influence of $\mathrm{AMH}$ produced by fetal Sertoli cells. If active $\mathrm{AMH}$ is not produced, owing to $A M H$ gene mutations, Müllerian ducts develop into uterus, fallopian tubes, and upper vagina notwithstanding normal virilization of external genitalia and urogenital sinus. PMDS can also be consecutive to mutations of the AMH receptor type II gene (AMHR2), but in this case testicular function is normal [reviewed in Ref. (54)]. PMDS should not be considered in patients with defects in the virilization of external genitalia. Gonadotrope activity is not affected during fetal life.

PRIMARY HYPOGONADISM ESTABLISHED IN THE SECOND AND THIRD TRIMESTERS

Whole testicular dysfunction: testicular regression syndrome

The existence of fully virilized external genitalia, i.e., completely fused scrotum and a urethral opening at the tip of the penis, is indicative of the existence of functional testes in the first trimester of gestation. However, the gonads may undergo regression (vanishing testes) due to torsion of the spermatic cord or to other unknown situations, resulting in a deficient or completely absent exposure to testicular hormones until the end of fetal life. The hypoandrogenism leads to scrotal hypotrophy and micropenis. Androgen and inhibin B insufficiency results in an exaggerated gonadotrope activity.

\section{Leydig cell-specific dysfunction: INSL3 deficiency}

Mutations in INSL3 lead to a rare form of Leydig cell-specific dysfunction without hypoandrogenism. Newborns are normally virilized but present with cryptorchidism, reflecting the defect in testicular descent [reviewed in Ref. (55)]. Because INSL3 has no effect on the gonadotrope, $\mathrm{LH}$ and FSH secretion are not disturbed in these individuals during fetal life.

\section{Sertoli cell-specific dysfunction: FSH receptor mutations}

As already discussed, Sertoli cell differentiation in early fetal life is not dependent on FSH; therefore, male fetuses with FSH receptor mutations secrete sufficient amounts of AMH to induce Müllerian duct regression. On the contrary, since FSH is an important Sertoli cell mitogen, FSH-R mutations lead to Sertoli cell hypoplasia and small testes. Adults have low sperm count, low inhibin B, and moderately elevated FSH (56). 
Table 3 | Clinical features in male patients with fetal-onset primary hypogonadism with Leydig cell-specific (steroidogenic) dysfunction.

\begin{tabular}{|c|c|c|c|c|}
\hline Gene & Protein & OMIM & Hormone levels & Associated clinical features \\
\hline LHCG-R & LH/CG receptor & \#238320 & $\downarrow \downarrow$ All steroids & None \\
\hline CYP11A1 & P450scc & \#613743 & $\downarrow \downarrow$ All steroids & Adrenal insufficiency \\
\hline CYP17A1 & P450c17 (17 $\alpha$-hydroxylase activity) & \#202110 & $\uparrow$ Pregnenolone & Adrenal insufficiency \\
\hline \multirow[t]{4}{*}{ CYP17A1 } & P450c17 (17,20-lyase activity) & \#202110 & $\uparrow 170 \mathrm{OH}$-pregnenolone & Adrenal insufficiency \\
\hline & & & $\uparrow 170 H$-progesterone & \\
\hline & & & $\uparrow$ Pregnenolone & \\
\hline & & & $\uparrow$ Progesterone & \\
\hline POR & P450 oxidoreductase & \#613571 & $\uparrow$ Progesterone & Antley-Bixler syndrome \\
\hline HSD3B2 & & & $\uparrow$ Pregnenolone & \\
\hline \multirow[t]{4}{*}{ HSD17B3 } & $17 \beta-H S D$ type 3 & \#264300 & $\uparrow$ Androstenedione & None \\
\hline & & & $\uparrow \mathrm{DHEA}$ & \\
\hline & & & $\uparrow 17 \mathrm{OH}$-progesterone & \\
\hline & & & $\uparrow 17 \mathrm{OH}$-pregnenolone & \\
\hline
\end{tabular}

OMIM, Online Mendelian Inheritance in Man locus, gene and phenotype numbers (http://www.ncbi.nlm.nih.gov/omim).

CENTRAL HYPOGONADISM ESTABLISHED IN THE SECOND AND THIRD TRIMESTERS

Whole testicular dysfunction: hypogonadotropic hypogonadism

As already discussed, deficient LH and FSH production by the fetal pituitary has no effect on sexual differentiation occurring in the ninth to thirteenth weeks of gestation, but do impact on genital development dependent on testicular function in the second and third trimesters of fetal life. Gonadotropin deficiency may result from an impaired differentiation of the gonadotrope in the context of a defective development of the pituitary primordium, and is therefore associated with multiple pituitary hormone deficiency. Alternatively, the defect may be restricted to the gonadotrope axis as a consequence of an impaired development, migration or function of the GnRH neurons, or of an impaired function of the gonadotrope. The lack of gonadotropin stimulus in this period of fetal development may result in small testes due to FSH deficiency, micropenis reflecting hypoandrogenism due to LH deficiency, and cryptorchidism as a sign of androgen and INSL3 insufficiency secondary to LH deficiency.

Multiple pituitary hormone deficiency. Congenital hypopituitarism occurs in approximately 1:4,000-1:10,000 newborns, with a 7:3 male-to-female ratio (57), and involves multiple pituitary cell lineages in approximately $80 \%$ of the cases. Mutations in genes involved in early pituitary differentiation and development usually result in multiple pituitary hormone deficiency including hypogonadotropic hypogonadism, usually due to pituitary hypoplasia. Although variable, there are a few clinical signs that may help in the identification of the underlying cause (Table 4) [reviewed in
Ref. $(58,59)]$. For instance, the association of congenital multiple pituitary hormone deficiency with septo-optic dysplasia (midline neural defects and optic nerve hypoplasia) has been observed in patients with mutations in HESX1, SOX2 and SOX3. Midline defects, coloboma and polydactyly are also present in HESX1 patients, anophthalmia or microphthalmia and esophageal atresia in SOX2 cases, and X-linked mental retardation in SOX 3 mutations. $L H X 3$ defects are present in patients with rigid and short cervical spine; LHX4 mutations can be found in individuals with abnormalities in the central skull base; GLI2 in patients with holoprosencephaly; PITX2 in patients with Axenfeld-Rieger syndrome (anomalies of anterior eye chamber, dental hypoplasia, craniofacial dysmorphism, and protuberant umbilicus); SIX6 in patients with absent optic chiasm and brain cortical atrophy, and OTX2 in patients with microphthalmia. Defects in late development factors, like PROP1 are present in non-syndromic patients with multiple pituitary hormone deficiencies. Currently, only $<15 \%$ of the etiologies of congenital hypopituitarism have been identified (60).

Isolated hypogonadotropic hypogonadism. Congenital isolated central hypogonadism can present as the only manifestation of the disorder (normosmic hypogonadotropic hypogonadism), or be associated with partial or complete loss of olfaction (Kallmann syndrome or anosmic hypogonadotropic hypogonadism), usually associated with other anatomical and/or neurological defects [reviewed in Ref. (61)].

Hyposmic/anosmic hypogonadotropic hypogonadism with or without other syndromic features results from mutations in the genes involved in the development and migration of the GnRH 
Table 4 | Clinical features in male patients with fetal-onset central hypogonadism associated with multiple pituitary hormone deficiency.

\begin{tabular}{|c|c|c|c|}
\hline Gene & OMIM & Other pituitary lineages affected & Associated clinical features \\
\hline HESX1 & \#182230 & $\begin{array}{l}\text { Somatotrope } \\
\text { Lactotrope } \\
\text { Thyrotrope } \\
\text { Corticotrope }\end{array}$ & $\begin{array}{l}\text { Septo-optic dysplasia } \\
\text { Midline defects } \\
\text { Coloboma } \\
\text { Polydactyly }\end{array}$ \\
\hline SOX2 & \#206900 & Somatotrope & $\begin{array}{l}\text { Septo-optic dysplasia } \\
\text { Anopthalmia/microphthalmia } \\
\text { Sensorineural defects } \\
\text { Esophageal atresia }\end{array}$ \\
\hline SOX3 & \#312000 & $\begin{array}{l}\text { Somatotrope } \\
\text { Thyrotrope } \\
\text { Corticotrope }\end{array}$ & Septo-optic dysplasia \\
\hline LHX4 & \#262700 & $\begin{array}{l}\text { Somatotrope } \\
\text { Thyrotrope } \\
\text { Corticotrope }\end{array}$ & $\begin{array}{l}\text { Hindbrain defects } \\
\text { Abnormality of central skull base }\end{array}$ \\
\hline GLI2 & \#610829 & $\begin{array}{l}\text { Somatotrope } \\
\text { Lactotrope } \\
\text { Thyrotrope } \\
\text { Corticotrope }\end{array}$ & Holoprosencephaly \\
\hline PITX2 & $\# 180500$ & $\begin{array}{l}\text { Somatotrope } \\
\text { Thyrotrope }\end{array}$ & $\begin{array}{l}\text { Axenfeld-Rieger syndrome (anomalies of anterior eye chamber, dental } \\
\text { hypoplasia, craniofacial dysmorphism and protuberant umbilicus) }\end{array}$ \\
\hline PROP1 & \#262600 & $\begin{array}{l}\text { Somatotrope } \\
\text { Thyrotrope } \\
\text { Corticotrope }\end{array}$ & $\begin{array}{l}\text { Intra- and extra-sellar cell mass, which may degenerate leading to empty } \\
\text { sella later in life }\end{array}$ \\
\hline
\end{tabular}

OMIM, Online Mendelian Inheritance in Man locus, gene and phenotype numbers (http://www.ncbi.nlm.nih.gov/omim).

neurons from the olfactory placode to the hypothalamus [reviewed in Ref. (61)]. The insufficient GnRH production is associated with olfactory bulb hypoplasia or aplasia in magnetic resonance imaging. Associated clinical manifestations may change according to the defective gene: KAL1, FGF8 and its receptor FGFR1, PROK2 and its receptor PROKR2, CHD7, NELF, HS6ST1, WDR11, SEMA3A (Table 5) [reviewed in Ref. (4)].

Normosmic isolated hypogonadotropic hypogonadism is the consequence of defects in genes involved in the regulation and function of the GnRH neuron or the gonadotrope. Impaired $\mathrm{GnRH}$ production may result from mutations in the GNRH1 gene or from defective regulation of the GnRH neuron by kisspeptin, neurokinin, or leptin signaling via their respective receptors. Mutations in the GNRHR gene, encoding the GnRH receptor present in the gonadotrope, are responsible for an impaired pituitary response to GnRH. In all the cases, except for defects in the neurokinin system, the secretion of both LH and FSH is impaired.

\section{Cell-specific dysfunction: dissociated hypogonadism}

Isolated LH deficiency. Congenital isolated LH deficiency with normal or high FSH production results from mutations in the LHB gene encoding the $\beta$ subunit of $\operatorname{LH}(62,63)$, and from defects in the neurokinin system responsible for the regulation of GnRH pulses. Neurokinin is a neuropeptide encoded by TAC3, which signals via the neurokinin receptor encoded by TACR3 (64, 65). Micropenis and cryptorchidism may be observed, as a consequence of the fetal hypoandrogenism during the second and 
Table 5 | Associated clinical features in male patients with fetal-onset isolated central hypogonadism due to defects in the migration of the GnRH neuron.

\begin{tabular}{|c|c|c|}
\hline Gene & OMIM & Associated clinical features \\
\hline$K A L 1$ & \#308700 & $\begin{array}{l}\text { Bimanual synkinesia, unilateral renal agenesis } \\
\text { Less frequently: palate defects (cleft lip/palate), } \\
\text { dental agenesis, ataxia, nystagmus, ear } \\
\text { anomalies, hearing loss, visual defects, } \\
\text { abnormal ocular movements }\end{array}$ \\
\hline $\begin{array}{l}\text { FGF8/ } \\
\text { FGFR1 }\end{array}$ & $\begin{array}{l}\# 612702 \\
\# 147950\end{array}$ & $\begin{array}{l}\text { Cleft lip/palate, bone anomalies (syndactilia), } \\
\text { dental agenesis } \\
\text { Less frequently: hearing loss, bimanual } \\
\text { synkinesia, ear anomalies, midline facial defects, } \\
\text { choanal atresia, cardiac defects, coloboma }\end{array}$ \\
\hline PROK2/ & \#610628 & Sleep disorder, high-arched palate, bimanual \\
\hline PROKR2 & \#244200 & $\begin{array}{l}\text { synkinesia, hearing loss, pectus excavatum, } \\
\text { hypodontia, obesity, nystagmus }\end{array}$ \\
\hline CHD7 & \#612370 & $\begin{array}{l}\text { Coloboma, heart defects, choanal atresia, } \\
\text { retardation of growth, genital anomalies, and } \\
\text { ear abnormalities }\end{array}$ \\
\hline$N E L F$ & \#614838 & None \\
\hline HS6ST1 & \#614880 & Cleft lip/palate, clinodactyly \\
\hline WDR11 & \#614858 & No \\
\hline SEMA3A & \#614897 & No \\
\hline
\end{tabular}

OMIM, Online Mendelian Inheritance in Man locus, gene and phenotype numbers (http://www.ncbi.nlm.nih.gov/omim).

third trimesters, but there is normal testes volume in the newborn and child, because FSH levels are adequate. A mild form of isolated LH deficiency is the underlying pathophysiology of the "fertile eunuch" syndrome, characterized by the absence of signs of hypoandrogenism until puberty, when eunuchoid proportions become apparent in males with normal testis volume and sperm production. Mutations in GNRHR (66) and LHB (67) genes have been described.

Isolated FSH deficiency. Male fetuses with insufficient FSH may develop small testes during the second and third trimesters owing to Sertoli cell hypoplasia. External genitalia do not show signs of hypoandrogenism since LH production is normal or elevated (68).

\section{COMBINED OR DUAL (PRIMARY AND CENTRAL) HYPOGONADISM}

DAX1 is a transcription factor encoded by NROB1 mapping to the short arm of the $\mathrm{X}$ chromosome. It has essential functions at several levels of the pituitary-gonadal and adrenal axes. DAX1 mutations result in a disorder characterized by adrenal hypoplasia and combined hypogonadism (Table 1). Testicular Sertoli and Leydig cell function is primarily affected resulting in moderately low hormone production; however, since the hypothalamic-pituitary axis is also defective, the gonadotrope is unable to increase $\mathrm{LH}$ and FSH production, despite the absence of an effective negative feedback loop.
Prader-Willi syndrome is another form of combined central and primary hypogonadism. This condition results from the lack of the paternally inherited chromosome 15 region q11-q13; this can be due to deletions in the paternal chromosome, to maternal disomy of $15 \mathrm{q} 11-\mathrm{q} 13$, or to a defective imprinting that silences the paternal chromosome 15. Several genes expressed exclusively from the paternal chromosome are believed to be involved in this syndrome (including MAGEL2, MKRN3, NDN, SNURF-SNRPN, and the HBII genes), although their underlying mechanism is not well understood (69). Hypogonadism is reflected in signs such as micropenis, cryptorchidism, scrotal hypoplasia, and microorchidism (70). However, the pathophysiology seems to be heterogeneous, and hypogonadism may be observed earlier or later in life, with a diverse participation of the hypothalamic-pituitary axis $(19,71-74)$.

\section{DIAGNOSTIC ASSESSMENT OF FETAL-ONSET MALE HYPOGONADISM}

The clinical and laboratory assessment of boys with suspected hypogonadism shows a wide spectrum and varies according to the etiology of the condition. Signs of hypoandrogenism are common to all; however, as already discussed, these signs will vary according to the period of fetal life in which hypogonadism is established. On the other hand, the evaluation of the other testicular hormones, and of any associated non-reproductive phenotype, may be extremely helpful in the diagnostic assessment of these boys.

\section{PATIENTS WITH AMBIGUOUS OR UNDERVIRILIZED EXTERNAL GENITALIA}

If fetal hypogonadism is the underlying cause for the existence of a DSD presenting with ambiguous or insufficiently virilized genitalia (i.e., hypospadias, bifid scrotum), the condition can only be due to primary gonadal failure. The need for a differential diagnosis between testicular dysgenesis (i.e., whole gonadal dysfunction) and a specific steroidogenic failure emerges. A few clinical signs can be helpful in certain cases: the existence of two palpable gonads $>1 \mathrm{~mL}$ is highly indicative of non-dysgenetic DSD (75), whereas the association of syndromic phenotypes - like skeletal dysplasia, macro/microcephaly, cardiac or renal defects, thalassemia, mental retardation, or minifascicular neuropathy orientate to gonadal dysgenesis (Table 2). Skeletal dysmorphisms may be present in patients with POR deficiency associated with the Antley-Bixler syndrome. Association with adrenal insufficiency is indicative of a non-dysgenetic steroidogenic defect (StAR, P450scc, P450c17, $\mathrm{POR}, 3 \beta-\mathrm{HSD}$ ), although mutations in SF1 resulting in gonadal dysgenesis are also a possible cause.

Results from hormonal laboratory assessment in the newborn and infant should be interpreted according to reference values for age. In DSD patients, this is particularly relevant in the first month of life (Figure 2) (15), when patients are studied for diagnosis. During the first 3-6 months after birth, basal hormone level determinations may be helpful (Figure 4). The existence of normal levels of testosterone, $\mathrm{AMH}$, and inhibin B rule out testicular dysfunction, and other etiologies of DSD should be sought (76, 77). When all testicular hormones are low and gonadotropins are elevated, gonadal dysgenesis is most likely [reviewed in Ref. (77)]. 

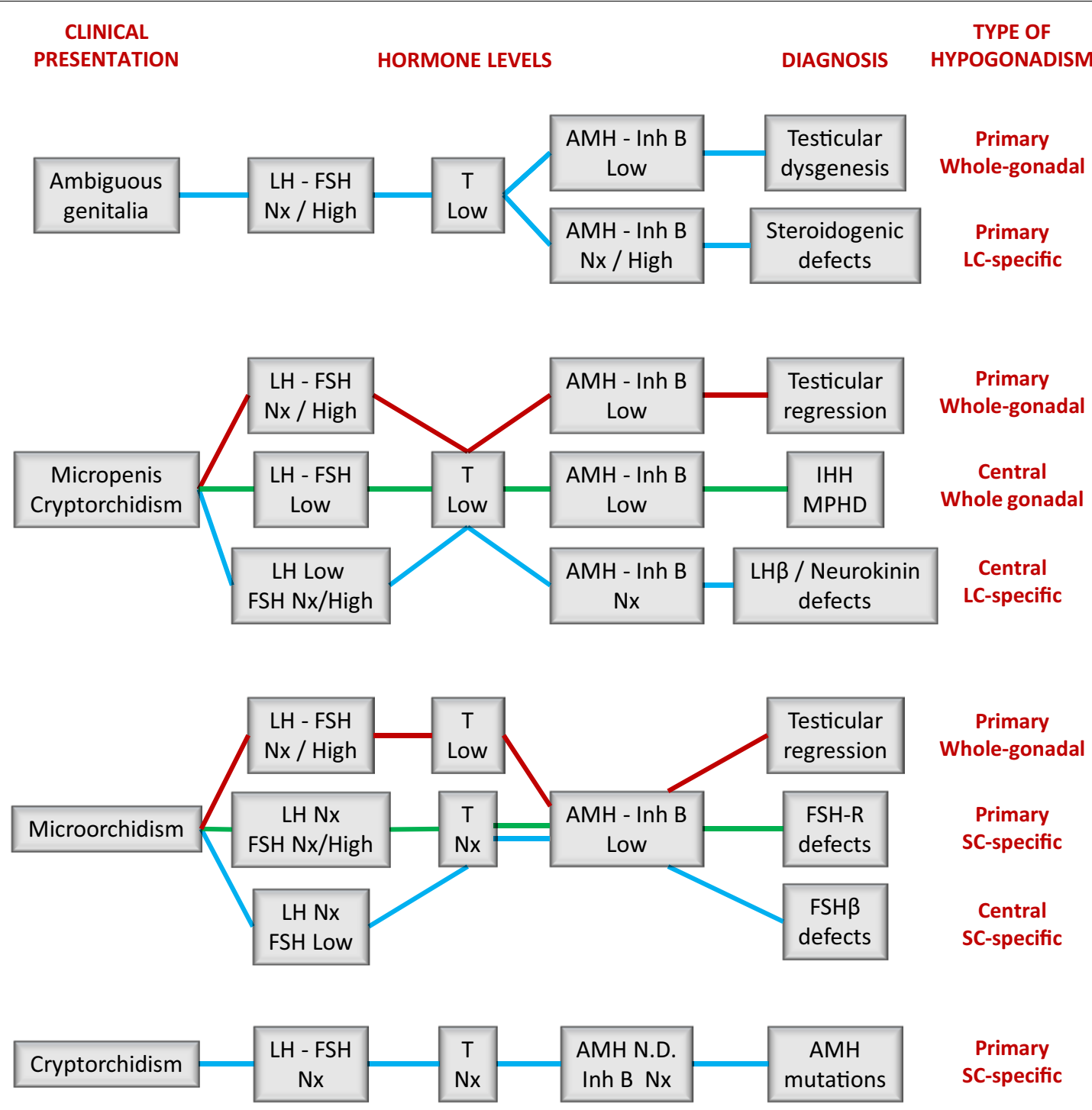

FIGURE 4 | A schematic guide for the interpretation of serum hormone levels in patients with fetal-onset male hypogonadism. $\mathrm{HH}$, isolated hypogonadotropic hypogonadism; Inh B, inhibin B; MPHD, multiple pituitary hormone deficiency; Nx, normal. Levels are considered as high, normal, or low as compared to the reference levels for newborns or prepubertal boys.
Low testosterone (53) with normal or elevated AMH (78) is characteristic of Leydig cell-specific hypogonadism. A prolonged hCG test (six IM injections every other day) and an ACTH test are necessary to distinguish between LHCG-R, StAR, and steroidogenic enzyme defects (Table 3). Gonadotropin levels may be somewhat elevated in the first months of life but they are usually normal during childhood in patients with steroidogenic defects (53). This is another example where primary hypogonadism is not hypergonadotropic in pediatric patients.

\section{PATIENTS WITH MALE GENITALIA}

The existence of normal male external genitalia rules out a fetal primary hypogonadism established in the first trimester, except for the rare form of Sertoli cell dysfunction due to $A M H$ mutations leading to PMDS (54). PMDS patients were most frequently present with bilateral cryptorchidism; serum AMH is undetectable but the other reproductive hormones are within the normal range for age.

Fetal-onset central hypogonadism and primary hypogonadism established in the second or third trimester have clinical signs of hypoandrogenism as a common feature: small penis and undescended gonads. Microorchidism can be indicative of insufficient FSH stimulus - i.e., central hypogonadism - or of a testicular regression syndrome - i.e., a primary hypogonadism that can progress to anorchism. Because the hypothalamic-pituitarytesticular axis remains active for 3-6 months after birth (17, 18 ), this period represents a window of opportunity to establish the diagnosis of hypogonadism (1). However, the diagnosis can still be suspected and confirmed during the rest of infancy and childhood. 
In some cases, the clinical presentation with cholestasis and/or hypoglycemia in the newborn or failure to thrive in infants can orientate the diagnosis to multiple pituitary hormone deficiency. Associated malformations in cerebral and hypothalamic-pituitary regions found on magnetic resonance imaging can be of further help (Table 4). A familial history of anosmia/hyposmia is suggestive of the diagnosis of isolated central hypogonadism, which could be reinforced by some anatomical or neurodevelopmental features in the infant or child (Table 5). Associated primary adrenal failure could orientate to adrenal hypoplasia congenital due to DAX1 mutations, whereas neonatal hypotonia and developmental delay may be indicative of Prader-Willi syndrome.

\section{In childhood, primary hypogonadism does not equate to hypergonadotropic hypogonadism}

The endocrine laboratory is necessary to certify the diagnosis of male hypogonadism. Basal gonadotropins, testosterone, and INSL3 are useful until the age of 3-6 months; thereafter dynamic stimulation tests are necessary to assess them. On the contrary, the Sertoli cell markers, AMH and inhibin B, are informative all through infancy and childhood without the need for stimulation tests. As discussed earlier, the occurrence of micropenis and non-palpable gonads prompts the differential diagnosis between central hypogonadism and testicular regression after the first trimester (Figure 4). If the patient is <3-6 months old, low levels of gonadotropins and Leydig and Sertoli cell hormones are suggestive of central hypogonadism $(16,79,80)$, whereas high gonadotropins associated with low/undetectable testicular hormones are diagnostic of primary hypogonadism. After the age of 6 months, basal testosterone and INSL3 are no longer informative because they are normally low/undetectable during the rest of infancy and childhood. Low gonadotropins also lose usefulness. Undetectable AMH $(81-83)$ and inhibin B $(83,84)$ are diagnostic of anorchia. The elevated levels of LH and FSH observed in these boys during the first years of life can subsequently decline to normal levels; therefore, serum gonadotropins within the reference range for age may not be informative during childhood (29). This is another clear example in pediatrics where primary hypogonadism is not hypergonadotropic.

\section{Central hypogonadism is not always hypogonadotropic}

The presence of micropenis, cryptorchidism, and microorchidism should prompt an early diagnosis of central hypogonadism, from which two main benefits may derive: first is to orientate the diagnosis of multiple pituitary hormone deficiency, favoring the opportune hormone replacement treatment (thyroid hormone, hydrocortisone, growth hormone). Second, as it has been postulated that the neonatal gonadotropic surge is physiologically important for testicular activity later in puberty and adulthood (85), early treatment with recombinant FSH and LH or hCG could be beneficial $(79,80)$. This also applies to isolated central hypogonadism. Analogously to the usefulness of testosterone and INSL3 to monitor Leydig cell response to LH/hCG (16), AMH (86) and inhibin B (87) are excellent markers of Sertoli cell response to FSH. In patients with a suspicion of central hypogonadism, AMH and inhibin B levels are suggestive if low but do not rule out the diagnosis if normal (88).
The hypoandrogenic states leading to micropenis and cryptorchidism - resulting from isolated $\mathrm{LH}$ deficiency due to mutations in the LH $\beta$ subunit or in the neurokinin system - are characterized by low LH and testosterone, but normal or elevated FSH. Interestingly, this central form of hypogonadism can even be hypergonadotropic, as observed in a young patient with delayed puberty, who had a functionally inactive but immunoreactive LH resulting in elevated serum levels associated with low testosterone (89).

Conversely, congenital isolated FSH $\beta$ deficiency, which presents with microorchidism but normal penile size and scrotal testes, has undetectable FSH and low inhibin B in adults with normal androgen with high LH after puberty $(89,90)$. No reports exist in childhood.

\section{CONCLUDING REMARKS}

Fetal hypogonadism of the first trimester is primary and results in dysgenetic or cell-specific forms of DSD. In the second and third trimesters, primary and central hypogonadism share signs of hypoandrogenism and defective INSL secretion - i.e., micropenis, hypoplastic scrotum and cryptorchidism - and of Sertoli cell hypoplasia - i.e., microorchidism. In prepubertal patients, classical serum markers, like gonadotropins and testosterone, are helpful essentially during the first 3-6 months of life. With the advent of $\mathrm{AMH}$ and inhibin $\mathrm{B}$, a biochemical diagnosis can also be envisaged during the rest of childhood. Clinical findings may also help in the diagnosis beyond early infancy. Finally, the pediatrician should not expect elevated gonadotropin levels during childhood to foresee a primary hypogonadism.

\section{AUTHOR CONTRIBUTIONS}

All authors contributed to manuscript writing and approved the final version.

\section{REFERENCES}

1. Grumbach MM. A window of opportunity: the diagnosis of gonadotropin deficiency in the male infant. J Clin Endocrinol Metab (2005) 90:3122-7. doi:10.1210/jc.2004-2465

2. Schwanzel-Fukuda M, Pfaff DW. Origin of luteinizing hormone-releasing hormone neurons. Nature (1989) 338:161-4. doi:10.1038/338161a0

3. Crowley WF. The developmental biology of the GnRH neurons. Mol Cell Endocrinol (2011) 346:1-3. doi:10.1016/j.mce.2011.06.023

4. Karges B, Neulen J, de Roux N, Karges W. Genetics of isolated hypogonadotropic hypogonadism: role of GnRH receptor and other genes. Int J Endocrinol (2012) 2012:147893. doi:10.1155/2012/147893

5. Romero CJ, Pine-Twaddell E, Radovick S. Novel mutations associated with combined pituitary hormone deficiency. J Mol Endocrinol (2011) 46:R93-102. doi:10.1530/JME-10-0133

6. Asa SL, Kovacs K, Singer W. Human fetal adenohypophysis: morphologic and functional analysis in vitro. Neuroendocrinology (1991) 53:562-72. doi:10.1159/ 000125775

7. Kaplan SL, Grumbach MM. The ontogenesis of human foetal hormones. II. Luteinizing hormone (LH) and follicle stimulating hormone (FSH). Acta Endocrinol (1976) 81:808-29.

8. Debieve F, Beerlandt S, Hubinont C, Thomas K. Gonadotropins, prolactin, inhibin A, inhibin B, and activin A in human fetal serum from midpregnancy and term pregnancy. J Clin Endocrinol Metab (2000) 85:270-4. doi:10.1210/ jcem.85.1.6249

9. Kuijper EA, Ket JC, Caanen MR, Lambalk CB. Reproductive hormone concentrations in pregnancy and neonates: a systematic review. Reprod Biomed Online (2013) 27:33-63. doi:10.1016/j.rbmo.2013.03.009 
10. Lasala C, Carré-Eusèbe D, Picard JY, Rey R. Subcellular and molecular mechanisms regulating anti-Mullerian hormone gene expression in mammalian and nonmammalian species. DNA Cell Biol (2004) 23:572-85. doi:10.1089/ 1044549041939232

11. Lasala C, Schteingart HF, Arouche N, Bedecarrás P, Grinspon RP, Picard JY, et al. SOX9 and SF1 are involved in cyclic AMP-mediated upregulation of antiMüllerian gene expression in the testicular prepubertal Sertoli cell line SMAT1. Am J Physiol Endocrinol Metab (2011) 301:E539-47. doi:10.1152/ajpendo.00187. 2011

12. Rey RA, Musse M, Venara M, Chemes HE. Ontogeny of the androgen receptor expression in the fetal and postnatal testis: its relevance on Sertoli cell maturation and the onset of adult spermatogenesis. Microsc Res Tech (2009) 72:787-95. doi:10.1002/jemt.20754

13. Cole LA. Biological functions of hCG and hCG-related molecules. Reprod Biol Endocrinol (2010) 8:102. doi:10.1186/1477-7827-8-102

14. Bay K, Main KM, Toppari J, Skakkebaek NE. Testicular descent: INSL3, testosterone, genes and the intrauterine milieu. Nat Rev Urol (2011) 8:187-96. doi:10.1038/nrurol.2011.23

15. Bergadá I, Milani C, Bedecarrás P, Andreone L, Ropelato MG, Gottlieb S, et al. Time course of the serum gonadotropin surge, inhibins, and anti-Mullerian hormone in normal newborn males during the first month of life. J Clin Endocrinol Metab (2006) 91:4092-8. doi:10.1210/jc.2006-1079

16. Bay K, Andersson AM. Human testicular insulin-like factor 3: in relation to development, reproductive hormones and andrological disorders. Int J Androl (2011) 34:97-109. doi:10.1111/j.1365-2605.2010.01074.x

17. Forest MG, Sizonenko PC, Cathiard AM, Bertrand J. Hypophyso-gonadal function in humans during the first year of life. 1. Evidence for testicular activity in early infancy. J Clin Invest (1974) 53:819-28. doi:10.1172/JCI107621

18. Kuiri-Hanninen T, Seuri R, Tyrvainen E, Turpeinen U, Hamalainen E, Stenman UH, et al. Increased activity of the hypothalamic-pituitary-testicular axis in infancy results in increased androgen action in premature boys. JClin Endocrinol Metab (2011) 96:98-105. doi:10.1210/jc.2010-1359

19. Hirsch HJ, Eldar-Geva T, Gross-Tsur V, Benarroch F, Roger M, Lahlou N. Normal insulin-like peptide-3 levels despite low testosterone in adult males with PraderWilli syndrome: variations in Leydig cell function from infancy through adulthood. J Clin Endocrinol Metab (2013) 98:E135-43. doi:10.1210/jc.2012-2171

20. Scott HM, Hutchison GR, Mahood IK, Hallmark N, Welsh M, De Gendt K, et al. Role of androgens in fetal testis development and dysgenesis. Endocrinology (2007) 148:2027-36. doi:10.1210/en.2006-1622

21. Müller J, Skakkebæk NE. Quantification of germ cells and seminiferous tubules by stereological examination of testicles from 50 boys who suffered from sudden death. Int J Androl (1983) 6:143-56. doi:10.1111/j.1365-2605.1983.tb00333.x

22. Grinspon RP, Bedecarrás P, Ballerini MG, Iñíguez G, Rocha A, Mantovani Rodrigues Resende EA, et al. Early onset of primary hypogonadism revealed by serum anti-Müllerian hormone determination during infancy and childhood in trisomy 21. Int J Androl (2011) 34:e487-98. doi:10.1111/j.1365-2605.2011. 01210.x

23. Bergadá I, Rojas G, Ropelato MG, Ayuso S, Bergadá C, Campo SM. Sexual dimorphism in circulating monomeric and dimeric inhibins in normal boys and girls from birth to puberty. Clin Endocrinol (1999) 51:455-60. doi:10.1046/j.1365-2265.1999.00814.x

24. Berensztein EB, Sciara MI, Rivarola MA, Belgorosky A. Apoptosis and proliferation of human testicular somatic and germ cells during prepuberty: high rate of testicular growth in newborns mediated by decreased apoptosis. J Clin Endocrinol Metab (2002) 87:5113-8. doi:10.1210/jc.2002-020032

25. Kalra B, Kumar A, Patel K, Patel A, Khosravi MJ. Development of a second generation inhibin B ELISA. J Immunol Methods (2010) 362:22-31. doi:10.1016/j.jim.2010.08.002

26. Aksglæde L, Sorensen K, Boas M, Mouritsen A, Hagen CP, Jensen RB, et al. Changes in anti-Mullerian hormone $(\mathrm{AMH})$ throughout the life span: a population-based study of 1027 healthy males from birth (cord blood) to the age of 69 years. JClin Endocrinol Metab (2010) 95:5357-64. doi:10.1210/jc.20101207

27. Ropelato MG, Escobar ME, Gottlieb S, Bergadá C. Gonadotropin secretion in prepubertal normal and agonadal children evaluated by ultrasensitive time-resolved immunofluorometric assays. Horm Res (1997) 48:164-72. doi:10.1159/000185508
28. Conte FA, Grumbach MM, Kaplan SL. A diphasic pattern of gonadotropin secretion in patients with the syndrome of gonadal dysgenesis. J Clin Endocrinol Metab (1975) 40:670-4. doi:10.1210/jcem-40-4-670

29. Grinspon RP, Ropelato MG, Bedecarrás P, Loreti N, Ballerini MG, Gottlieb S, et al. Gonadotrophin secretion pattern in anorchid boys from birth to pubertal age: pathophysiological aspects and diagnostic usefulness. Clin Endocrinol (2012) 76:698-705. doi:10.1111/j.1365-2265.2011.04297.x

30. Raivio T, Dunkel L. Inverse relationship between serum inhibin B and FSH levels in prepubertal boys with cryptorchidism. Pediatr Res (1999) 46:496-500. doi:10.1203/00006450-199911000-00002

31. Bergadá I, Del Toro K, Katz O, Chemes H, Campo SM. Serum inhibin B concentration in a prepubertal boy with gynecomastia and Peutz-Jeghers syndrome. J Pediatr Endocrinol Metab (2000) 13:101-3. doi:10.1515/JPEM.2000. 13.1.101

32. Pasqualini T, Chemes H, Rivarola MA. Testicular testosterone levels during puberty in cryptorchidism. Clin Endocrinol (1981) 15:545-54. doi:10.1111/j. 1365-2265.1981.tb00700.x

33. Page ST. Physiologic role and regulation of intratesticular sex steroids. Curr Opin Endocrinol Diabetes Obes (2011) 18:217-23. doi:10.1097/MED. 0b013e328345d50e

34. Raivio T, Perheentupa A, McNeilly AS, Groome NP, Anttila R, Siimes MA, et al. Biphasic increase in serum inhibin B during puberty: a longitudinal study of healthy Finnish boys. Pediatr Res (1998) 44:552-6. doi:10.1203/00006450199810000-00014

35. Crofton PM, Illingworth PJ, Groome NP, Stirling HF, Swanston I, Gow S, et al. Changes in dimeric inhibin A and B during normal early puberty in boys and girls. Clin Endocrinol (1997) 46:109-14. doi:10.1046/j.1365-2265.1997.d011744.x

36. Ferlin A, Garolla A, Rigon F, Rasi CL, Lenzi A, Foresta C. Changes in serum insulin-like factor 3 during normal male puberty. J Clin Endocrinol Metab (2006) 91:3426-31. doi:10.1210/jc.2006-0821

37. Rey RA, Grinspon RP, Gottlieb S, Pasqualini T, Knoblovits P, Aszpis S, et al. Male hypogonadism: an extended classification based on a developmental, endocrine physiology-based approach. Andrology (2013) 1:3-16. doi:10.1111/j.2047-2927. 2012.00008.x

38. Ottolenghi C, McElreavey K. Deletions of $9 p$ and the quest for a conserved mechanism of sex determination. Mol Genet Metab (2000) 71:397-404. doi:10.1006/mgme.2000.3060

39. Bardoni B, Zanaria E, Guioli S, Floridia G, Worley KC, Tonini G, et al. A dosage sensitive locus at chromosome Xp21 is involved in male to female sex reversal. Nat Genet (1994) 7:497-501. doi:10.1038/ng0894-497

40. Biason-Lauber A. Control of sex development. Best Pract Res Clin Endocrinol Metab (2010) 24:163-86. doi:10.1016/j.beem.2009.12.002

41. Veitia R, Ion A, Barbaux S, Jobling MA, Souleyreau N, Ennis K, et al. Mutations and sequence variants in the testis-determining region of the $\mathrm{Y}$ chromosome in individuals with a 46,XY female phenotype. Hum Genet (1997) 99:648-52. doi:10.1007/s004390050422

42. Fukami M, Wada Y, Miyabayashi K, Nishino I, Hasegawa T, Nordenskjöld A, et al. CXorf6 is a causative gene for hypospadias. Nat Genet (2006) 38:1369-71. doi:10.1038/ng1900

43. Kohler B, Lin L, Mazen I, Cetindag C, Biebermann H, Akkurt I, et al. The spectrum of phenotypes associated with mutations in steroidogenic factor 1 (SF-1, NR5A1, Ad4BP) includes severe penoscrotal hypospadias in 46,XY males without adrenal insufficiency. Eur J Endocrinol (2009) 161:237-42. doi:10.1530/EJE-09-0067

44. Allali S, Muller JB, Brauner R, Lourenco D, Boudjenah R, Karageorgou V, et al. Mutation analysis of NR5Al encoding steroidogenic factor 1 in 77 patients with 46, XY disorders of sex development (DSD) including hypospadias. PLoS One (2011) 6:e24117. doi:10.1371/journal.pone.0024117

45. Fallat ME, Donahoe PK. Intersex genetic anomalies with malignant potential. Curr Opin Pediatr (2006) 18:305-11. doi:10.1097/01.mop.0000193316.60580.d7

46. Haldin CE, LaBonne C. SoxE factors as multifunctional neural crest regulatory factors. Int J Biochem Cell Biol (2010) 42:441-4. doi:10.1016/j.biocel.2009.11.014

47. Umehara F, Tate G, Itoh K, Yamaguchi N, Douchi T, Mitsuya T, et al. A novel mutation of desert hedgehog in a patient with 46,XY partial gonadal dysgenesis accompanied by minifascicular neuropathy. Am J Hum Genet (2000) 67:1302-5. doi:10.1016/S0002-9297(07)62958-9 
48. Canto P, Söderlund D, Reyes E, Méndez JP. Mutations in the desert hedgehog (DHH) gene in patients with 46,XY complete pure gonadal dysgenesis. J Clin Endocrinol Metab (2004) 89:4480-3. doi:10.1210/jc.2004-0863

49. Reardon W, Gibbons RJ, Winter RM, Baraitser M. Male pseudohermaphroditism in sibs with the alpha-thalassemia/mental retardation (ATR-X) syndrome. Am J Med Genet (1995) 55:285-7. doi:10.1002/ajmg.1320550308

50. Pearlman A, Loke J, Le CC, White S, Chin L, Friedman A, et al. Mutations in MAP3K1 cause 46,XY disorders of sex development and implicate a common signal transduction pathway in human testis determination. Am J Hum Genet (2010) 87:898-904. doi:10.1016/j.ajhg.2010.11.003

51. Puffenberger EG, Hu-Lince D, Parod JM, Craig DW, Dobrin SE, Conway AR, et al. Mapping of sudden infant death with dysgenesis of the testes syndrome (SIDDT) by a SNP genome scan and identification of TSPYL loss of function. Proc Natl Acad Sci U S A (2004) 101:11689-94. doi:10.1073/pnas.0401194101

52. Main KM, Skakkebæk NE, Virtanen HE, Toppari J. Genital anomalies in boys and the environment. Best Pract Res Clin Endocrinol Metab (2010) 24:279-89. doi:10.1016/j.beem.2009.10.003

53. Mendonça BB, Costa EM, Belgorosky A, Rivarola MA, Domenice S. 46,XY DSD due to impaired androgen production. Best Pract Res Clin Endocrinol Metab (2010) 24:243-62. doi:10.1016/j.beem.2009.11.003

54. Josso N, Rey R, Picard JY. Testicular anti-Mullerian hormone: clinical applications in DSD. Semin Reprod Med (2012) 30:364-73. doi:10.1055/s-00321324719

55. Ivell R, Anand-Ivell R. Biological role and clinical significance of insulin-like peptide 3. Curr Opin Endocrinol Diabetes Obes (2011) 18:210-6. doi:10.1097/ MED.0b013e3283453fe6

56. Tapanainen JS, Aittomaki K, Min J, Vaskivuo T, Huhtaniemi IT. Men homozygous for an inactivating mutation of the follicle-stimulating hormone (FSH) receptor gene present variable suppression of spermatogenesis and fertility. Nat Genet (1997) 15:205-6. doi:10.1038/ng0297-205

57. van Tijn DA, de Vijlder JJ, Verbeeten B Jr, Verkerk PH, Vulsma T. Neonatal detection of congenital hypothyroidism of central origin. J Clin Endocrinol Metab (2005) 90:3350-9. doi:10.1210/jc.2004-2444

58. Romero CJ, Nesi-França S, Radovick S. The molecular basis of hypopituitarism. Trends Endocrinol Metab (2009) 20:506-16. doi:10.1016/j.tem.2009.06.005

59. Davis SW, Castinetti F, Carvalho LR, Ellsworth BS, Potok MA, Lyons RH, et al. Molecular mechanisms of pituitary organogenesis: in search of novel regulatory genes. Mol Cell Endocrinol (2010) 323:4-19. doi:10.1016/j.mce.2009. 12.012

60. Castinetti F, Reynaud R, Saveanu A, Barlier A, Brue T. Genetic causes of combined pituitary hormone deficiencies in humans. Ann Endocrinol (Paris) (2012) 73:53-5. doi:10.1016/j.ando.2012.03.025

61. Balasubramanian R, Crowley WF Jr. Isolated GnRH deficiency: a disease model serving as a unique prism into the systems biology of the $\mathrm{GnRH}$ neuronal network. Mol Cell Endocrinol (2011) 346:4-12. doi:10.1016/j.mce.2011.07.012

62. Valdes-Socin H, Salvi R, Daly AF, Gaillard RC, Quatresooz P, Tebeu PM, et al. Hypogonadism in a patient with a mutation in the luteinizing hormone betasubunit gene. N Engl J Med (2004) 351:2619-25. doi:10.1056/NEJMoa040326

63. Lofrano-Porto A, Barra GB, Giacomini LA, Nascimento PP, Latronico AC, Casulari LA, et al. Luteinizing hormone beta mutation and hypogonadism in men and women. N Engl J Med (2007) 357:897-904. doi:10.1056/NEJMoa071999

64. Topaloglu AK, Reimann F, Guclu M, Yalin AS, Kotan LD, Porter KM, et al. TAC3 and TACR3 mutations in familial hypogonadotropic hypogonadism reveal a key role for neurokinin B in the central control of reproduction. Nat Genet (2009) 41:354-8. doi:10.1038/ng.306

65. Brioude F, Bouligand J, Trabado S, Francou B, Salenave S, Kamenicky P, et al. Non-syndromic congenital hypogonadotropic hypogonadism: clinical presentation and genotype-phenotype relationships. Eur J Endocrinol (2010) 162:835-51. doi:10.1530/EJE-10-0083

66. Pitteloud N, Boepple PA, DeCruz S, Valkenburgh SB, Crowley WF Jr, Hayes FJ. The fertile eunuch variant of idiopathic hypogonadotropic hypogonadism: spontaneous reversal associated with a homozygous mutation in the gonadotropin-releasing hormone receptor. J Clin Endocrinol Metab (2001) 86:2470-5. doi:10.1210/jc.86.6.2470

67. Shiraishi K, Naito K. Fertile eunuch syndrome with the mutations (Trp8Arg and Ile15Thr) in the beta subunit of luteinizing hormone. Endocr J (2003) 50:733-7. doi:10.1507/endocri.50.733
68. Layman LC, Porto AL, Xie J, da Motta LA, da Motta LD, Weiser W, et al. FSH beta gene mutations in a female with partial breast development and a male sibling with normal puberty and azoospermia. J Clin Endocrinol Metab (2002) 87:3702-7. doi:10.1210/jc.87.8.3702

69. Shao XY, Zhang R, Hu C, Wang CR, Lu JY, Qin W, et al. Precise microdeletion detection of Prader-Willi syndrome with array comparative genome hybridization. Biomed Environ Sci (2010) 23:194-8. doi:10.1016/S08953988(10)60052-9

70. Eiholzer U, L'Allemand D, Rousson V, Schlumpf M, Gasser T, Girard J, et al. Hypothalamic and gonadal components of hypogonadism in boys with Prader-Labhart-Willi syndrome. J Clin Endocrinol Metab (2006) 91:892-8. doi:10.1210/jc.2005-0902

71. Fillion M, Deal CL, Van Vliet G. Normal minipuberty of infancy in boys with Prader-Willi syndrome. J Pediatr (2006) 149:874-6. doi:10.1016/j.jpeds.2006. 08.077

72. Hirsch HJ, Eldar-Geva T, Benarroch F, Rubinstein O, Gross-Tsur V. Primary testicular dysfunction is a major contributor to abnormal pubertal development in males with Prader-Willi syndrome. J Clin Endocrinol Metab (2009) 94:2262-8. doi:10.1210/jc.2008-2760

73. Radicioni AF, Di GG, Grugni G, Cuttini M, Losacco V, Anzuini A, et al. Multiple forms of hypogonadism of central, peripheral or combined origin in males with Prader-Willi syndrome. Clin Endocrinol (2012) 76:72-7. doi:10.1111/j.1365-2265.2011.04161.x

74. Siemensma EP, de Lind van Wijngaarden RF, Otten BJ, de Jong FH, HokkenKoelega AC. Testicular failure in boys with Prader-Willi syndrome: longitudinal studies of reproductive hormones. J Clin Endocrinol Metab (2012) 97:E452-9. doi:10.1210/jc.2011-1954

75. Arcari AJ, Bergadá I, Rey RA, Gottlieb S. Predictive value of anatomical findings and karyotype analysis in the diagnosis of patients with disorders of sexual development. Sex Dev (2007) 1:222-9. doi:10.1159/000104772

76. Rey RA, Codner E, Iñíguez G, Bedecarrás P, Trigo R, Okuma C, et al. Low risk of impaired testicular Sertoli and Leydig cell functions in boys with isolated hypospadias. J Clin Endocrinol Metab (2005) 90:6035-40. doi:10.1210/jc.20051306

77. Rey RA, Grinspon RP. Normal male sexual differentiation and aetiology of disorders of sex development. Best Pract Res Clin Endocrinol Metab (2011) 25:221-38. doi:10.1016/j.beem.2010.08.013

78. Rey RA, Belville C, Nihoul-Fékété C, Michel-Calemard L, Forest MG, Lahlou $\mathrm{N}$, et al. Evaluation of gonadal function in 107 intersex patients by means of serum anti-Müllerian hormone measurement. J Clin Endocrinol Metab (1999) 84:627-31. doi:10.1210/jc.84.2.627

79. Bouvattier C, Maione L, Bouligand J, Dodé C, Guiochon-Mantel A, Young J. Neonatal gonadotropin therapy in male congenital hypogonadotropic hypogonadism. Nat Rev Endocrinol (2012) 8:172-82. doi:10.1038/nrendo.2011.164

80. Bougnères P, François M, Pantalone L, Rodrigue D, Bouvattier C, Demesteere E, et al. Effects of an early postnatal treatment of hypogonadotropic hypogonadism with a continuous subcutaneous infusion of recombinant follicle-stimulating hormone and luteinizing hormone. J Clin Endocrinol Metab (2008) 93:2202-5. doi:10.1210/jc.2008-0121

81. Josso N. Anti-Müllerian hormone and Sertoli cell function. Horm Res (1992) 38(Suppl 2):72-6. doi:10.1159/000182602

82. Lee MM, Donahoe PK, Silverman BL, Hasegawa T, Hasegawa Y, Gustafson ML, et al. Measurements of serum Müllerian inhibiting substance in the evaluation of children with nonpalpable gonads. N Engl J Med (1997) 336:1480-6. doi:10.1056/NEJM199705223362102

83. Brauner R, Neve M, Allali S, Trivin C, Lottmann H, Bashamboo A, et al. Clinical, biological and genetic analysis of anorchia in 26 boys. PLoS One (2011) 6:e23292. doi:10.1371/journal.pone.0023292

84. Kubini K, Zachmann M, Albers N, Hiort O, Bettendorf M, Wolfle J, et al. Basal inhibin $\mathrm{B}$ and the testosterone response to human chorionic gonadotropin correlate in prepubertal boys. J Clin Endocrinol Metab (2000) 85:134-8. doi:10.1210/jcem.85.1.6285

85. Hadziselimovic F, Zivkovic D, Bica DT, Emmons LR. The importance of minipuberty for fertility in cryptorchidism. J Urol (2005) 174:1536-9. doi:10.1097/ 01.ju.0000181506.97839.b0

86. Young J, Chanson P, Salenave S, Noël M, Brailly S, O’Flaherty M, et al. Testicular anti-Mullerian hormone secretion is stimulated by recombinant human FSH 
in patients with congenital hypogonadotropic hypogonadism. J Clin Endocrinol Metab (2005) 90:724-8. doi:10.1210/jc.2004-0542

87. Raivio T, Toppari J, Perheentupa A, McNeilly AS, Dunkel L. Treatment of prepubertal gonadotrophin-deficient boys with recombinant human folliclestimulating hormone. Lancet (1997) 350:263-4. doi:10.1016/S0140-6736(05) 62227-1

88. Vizeneux A, Hilfiger A, Bouligand J, Pouillot M, Brailly-Tabard S, Bashamboo A, et al. Congenital hypogonadotropic hypogonadism during childhood: presentation and genetic analyses in 46 boys. PLoS One (2013) 8:e77827. doi:10.1371/journal.pone.0077827

89. Huhtaniemi IT. The role of mutations affecting gonadotrophin secretion and action in disorders of pubertal development. Best Pract Res Clin Endocrinol Metab (2002) 16:123-38. doi:10.1053/beem.2002.0185

90. Lindstedt G, Nyström E, Matthews C, Ernest I, Janson PO, Chatterjee K. Follitropin (FSH) deficiency in an infertile male due to $\mathrm{FSH} \beta$ gene mutation. A syndrome of normal puberty and virilization but under-developed testicles with azoospermia, low FSH but high lutropin and normal serum testosterone concentrations. Clin Chem Lab Med (1998) 36:663-5. doi:10.1515/ CCLM.1998.118
Conflict of Interest Statement: Rodolfo A. Rey and Patricia Bedecarrás have received honoraria from CONICET (Argentina) for technology services using the AMH ELISA. All other authors report no conflicts of interest.

Received: 22 December 2013; paper pending published: 24 February 2014; accepted: 27 March 2014; published online: 07 May 2014.

Citation: Grinspon RP, Loreti N, Braslavsky D, Valeri C, Schteingart H, Ballerini MG, Bedecarrás P, Ambao V, Gottlieb S, Ropelato MG, Bergadá I, Campo SM and Rey RA (2014) Spreading the clinical window for diagnosing fetal-onset hypogonadism in boys. Front. Endocrinol. 5:51. doi: 10.3389/fendo.2014.00051

This article was submitted to Pediatric Endocrinology, a section of the journal Frontiers in Endocrinology.

Copyright $\odot 2014$ Grinspon, Loreti, Braslavsky, Valeri, Schteingart, Ballerini, Bedecarrás, Ambao, Gottlieb, Ropelato, Bergadá, Campo and Rey. This is an open-access article distributed under the terms of the Creative Commons Attribution License (CC BY). The use, distribution or reproduction in other forums is permitted, provided the original author(s) or licensor are credited and that the original publication in this journal is cited, in accordance with accepted academic practice. No use, distribution or reproduction is permitted which does not comply with these terms. 